\title{
Communication
}

[Comunicação]

\section{Proleptus acutus Dujardin, 1845 (Nematoda, Physalopteridae) parasite of rays Zapteryx brevirostris Müller \& Henle, 1841 (Rhinobatiformes, Rhinobatidae) in Brazil}

\author{
[Proleptus acutus Dujardin, 1845 (Nematoda, Physalopteridae) parasita de raias Zapteryx brevirostris \\ Müller \& Henle, 1841 (Rhinobatiformes, Rhinobatidae) no Brasil]

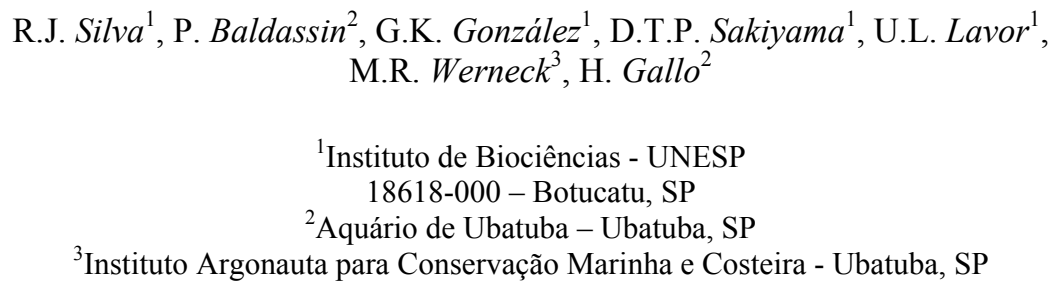

Zapteryx brevirostris is a common ray found in the coast of Brazil. It occurs from the northeastern Brazil to north of Argentina. It reaches $100 \mathrm{~cm}$ length and live until $120 \mathrm{~m}$ under the surface (Figueiredo, 1977; Menni and Sthemann, 2000).

Núñez (1971) studied the parasites of elasmobranches from Argentina and reported the occurrence of Acanthobothrium zapterycum, Echinobothrium pigmentatum, and plerocercoids of Phillobothrium sp. and Acanthobothrium sp. in the intestine of $Z$. brevirostris.

However, studies on the helminth fauna of $Z$. brevirostris are rare. The aim of the present study was to report the occurrence of Proleptus acutus in rays from Brazilian coast.

The fish were collected in Ubatuba, State of São Paulo. All rays included in the study $(n=20 ; 11$ males and nine females) were found dead after coming into contact with fishing. The animals were donated to the Ubatuba Aquarium where they were frozen.

The necropsies revealed that only the gastrointestinal system was parasitized by helminthes and only nematodes species were found. These nematodes were collected, fixed in AFA solution, and the specimens were deposited in the Helminthological Collection of the Instituto de Biociências at the Universidade Estadual Paulista, Botucatu, State of São Paulo, Brazil (CHIBB numbers 1354 to 1368,1372 to 1375,1377 to 1378 , and 1380 to 1381 ). Six males and six females were clarified with lactophenol and the morphology was analyzed using the Leica Qwin Lite 3.1 computerized system. Prevalence and intensity of infection were calculated according to Bush et al. (1997).

Fourteen $(70 \%)$ rays were parasitized and the nematodes were collected in the stomach, intestines, and both organs of one $(5 \%)$, six $(30 \%)$, and seven $(35 \%)$ rays, respectively. The prevalence of infection in the stomach and intestines was similar in males; but in females, it was higher in the intestines. The number of recovered parasites ranged from one to 38 in the stomach and from one to 58 in the intestines. The number of parasites collected in an individual ranged from one to 76 (Table 1).

The main characteristics of the collected nematodes were: mouth bounded by two simple pseudolabia, each bearing two submedian papillae; large conical projection on the inner surface of each pseudolabia; esophagus divided in two portions, the anterior was muscular, short, and ended after the nervous ring, the second was glandular, long, and more dilated in the posterior 
portion; two cervical papillae anterior to the nerve ring; nerve ring present, well visible; the male presented tail ventrally coiled, with a very broad caudal alae with eight pairs of pedunculate and riblike papillae (three preanal and five postanal); two unequal spicules, the smaller was broad at the base and tapering rapidly towards the tip, and the larger presented a long tubular shaft widening at the posterior end due to ala narrowing sharply before the tip (Fig. 1); the females presented a conical tail, vulva situated near the posterior end; vagina not long; two parallel uterine branches; anus subterminal; eggs were ovoid and contained coiled embryos when developed. Morphometric data of the males and females are presented in Table 2.
The nematodes were identified as $P$. acutus. Nematodes of the genus Proleptus have been reviewed by Specian et al. (1975), whose gave a complete key to the identification of the species. Proleptus acutus was firstly reported in Raja clavata, $R$. circularis, and Mustelus laevis (Baylis, 1933). In South America, this nematode was previously reported infecting Sympterya bonapartei in Argentina (Romera, 1993) and Rhinobatos planiceps in Chile (Dailey and Carvajal, 1976). This is the first report on the occurrence of $P$. acutus in $Z$. brevirostris and the first occurrence in Brazil. These data contribute to the knowledge of the helminth fauna of rays in the Brazilian coast.

Keywords: ray, Zapteryx brevirostris, Proleptus acutus, nematode, prevalence

Table 1. Parasitological indexes of Zapteryx brevirostris (Rhinobatiformes, Rhinobatidae) from Ubatuba, State of São Paulo, Brazil, infected by Proleptus acutus (Nematoda, Physalopteridae)

\begin{tabular}{lccccccc}
\hline \multicolumn{1}{c}{ Gender } & Length $(\mathrm{cm})$ & \multicolumn{3}{c}{ Stomach } & \multicolumn{3}{c}{ Intestines } \\
Male & & IF/EF & P (\%) & MII (R) & IF/EF & P (\%) & MII (R) \\
Female & $42.2(32-48)$ & $5 / 11$ & 45.5 & $15.6(1-38)$ & $6 / 11$ & 54.5 & $6.3(1-11)$ \\
Total & $42.3(27-49)$ & $3 / 9$ & 33.3 & $7.0(1-18)$ & $7 / 9$ & 77.8 & $11.1(1-58)$ \\
\hline
\end{tabular}

IF: infected fish; EF: examined fish; MII: mean intensity of infection; R: range - minimum and maximum values; P: prevalence.
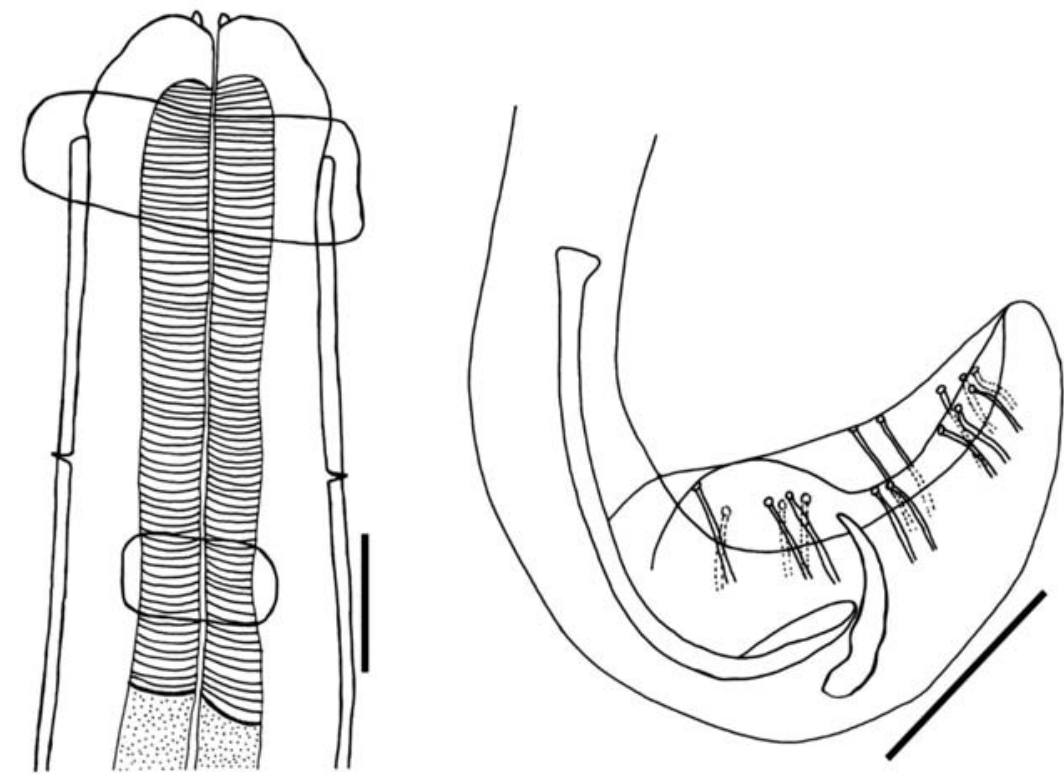

Figure 1. Proleptus acutus (Nematoda, Physalopteridae) collected in Zapteryx brevirostris (Rhinobatiformes, Rhinobatidae) from Ubatuba, State of São Paulo, Brazil: detail of the anterior extremity (left, bar $100 \mu \mathrm{m})$ and caudal alae in a male (right, bar $500 \mu \mathrm{m}$ ). 
Table 2. Morphometric data of the males $(\mathrm{n}=6)$ and females $(\mathrm{n}=6)$ of Proleptus acutus (Nematoda, Physalopteridae) collected in the stomach and intestines of Zapteryx brevirostris (Rhinobatiformes, Rhinobatidae) from Ubatuba, State of São Paulo, Brazil

\begin{tabular}{|c|c|c|c|c|c|c|}
\hline \multirow{2}{*}{$\begin{array}{c}\text { Variable } \\
(\mu \mathrm{m})\end{array}$} & \multicolumn{3}{|c|}{ Male } & \multicolumn{3}{|c|}{ Female } \\
\hline & Mean & Minimum & Maximum & Mean & Minimum & Maximum \\
\hline Length & $34,660.1$ & $31,044.1$ & $40,722.2$ & $35,296.9$ & $28,438.7$ & $43,642.4$ \\
\hline Width & 412.4 & 369.5 & 459.1 & 450.5 & 396.8 & 533.9 \\
\hline Buccal cavity & 63.4 & 53.8 & 75.0 & 58.1 & 51.2 & 67.1 \\
\hline Muscular esophagus & 519.8 & 479.1 & 565.7 & 507.1 & 364.9 & 616.6 \\
\hline Glandular esophagus & $3,806.3$ & $3,412.3$ & $4,169.1$ & $3,886.5$ & 2917.2 & $4,760.0$ \\
\hline Nerve ring ${ }^{\mathrm{a}}$ & 428.9 & 400.4 & 441.4 & 425.3 & 377.1 & 453.5 \\
\hline Larger spicule & $1,630.3$ & $1,485.9$ & $1,881.2$ & - & - & - \\
\hline Smaller spicule & 567.6 & 481.8 & 682.9 & - & - & - \\
\hline Cloaca & $1,183.7$ & 973.2 & $1,487.1$ & - & - & - \\
\hline Vulva $^{\mathrm{b}}$ & - & - & - & 771.5 & 639.2 & $1,197.7$ \\
\hline Anus $^{c}$ & - & - & - & 381.8 & 224.1 & 654.7 \\
\hline \multicolumn{7}{|l|}{ Eggs } \\
\hline Length & - & - & - & 35.1 & 28.7 & 42.3 \\
\hline Width & - & - & - & 26.8 & 22.9 & 30.4 \\
\hline
\end{tabular}

a: distance to the anterior end; $\mathrm{b}$ and $\mathrm{c}$ : distance to the posterior end.

\section{RESUMO}

Relata-se a ocorrência de Proleptus acutus Dujardin, 1845 (Nematoda, Physalopteridae) parasitando Zapteryx brevirostris Müller \& Henle, 1841 (Rhinobatiformes, Rhinobatidae) em Ubatuba, estado de São Paulo, Brasil. Vinte raias foram analisadas e P. acutus foi encontrado no estômago e intestinos de 14 (70\%) animais. Este é o primeiro relato da ocorrência dessa espécie de nematóide em Z $\mathrm{Z}$. brevirostris no Brasil.

Palavras-chave: raia, Zapteryx brevirostris, Proleptus acutus, nematóide, prevalência

\section{REFERENCES}

BAYLIS, H.A. On the nematode genus Proleptus. Ann. Mag. Nat. Hist., v.12, p.325-335, 1933.

BUSH, A.O.; LAFFERTY, K.D.; LOTZ, J. et al. Parasitology meets ecology in its own terms: Margulis et al. revisited. J. Parasitol., v.83, p.575-583, 1997.

DAILEY, M.D.; CARVAJAL, J. Helminth parasites of Rhinobatos planiceps Garman 1880, including two new species of cestodes, with comments on host specificity of the genus Rhinebothrium Linton 1890. J. Parasitol., v.62, p.939-942, 1976.

FIGUEIREDO, J.L. Manual de peixes marinhos do Sudeste do Brasil. I. Introdução, cações, raias e quimeras. São Paulo: Museu de Zoologia USP, 1977. 104p.
MENNI, R.C.; STHEMANN, M.F.W. Distribution, environment and biology of batoid fishes of Argentina, Uruguay and Brazil. A review. Rev. Mus. Argent. Cienc. Nat., v.2, p.69109, 2000.

NÚÑEZ, M.O. Estudios preliminares sobre la fauna parasitaria de algunos elasmobranquios del litoral Bonaerense, Mar del Plata, Argentina. I. Cestodes y trematodes de Psammobatis microps (Günther) y Zapteryx brevirostris (Mueller y Henle). Physis, v.30, p.425-446, 1971.

ROMERA, S.A. Proleptus acutus (Nematoda: Physalopteridae), a parasite from an Argentinian skate, Sympterygia bonapartei (Pisces: Rajidae). J. Parasitol., v.79, p.620-623, 1993.

SPECIAN, R.D.; UBELAKER, J.E.; DAILEY, M.D. Neoleptus gen. $\mathrm{n}$. and a revision of the genus Proleptus Dujardin, 1845. Proc. Helminthol. Soc. Wash., v.42, p.14-21, 1975. 